\title{
PENDAMPINGAN PENYUSUNAN SILABUS PENGAJIAN MAJELIS TAKLIM AT-TAQWA DESA MUARA BATUN KECAMATAN JEJAWI KABUPATEN OGAN KOMERING ILIR
}

\author{
Firmansyah $^{1}$ \\ ${ }^{1}$ Program Studi Pendidikan Agama Islam Fakultas Ilmu Tarbiyah dan Keguruan \\ Universitas Islam Negeri Raden Fatah Palembang \\ e-mail: firmansyah_uin@radenfatah.ac.id
}

\begin{abstract}
Abstrak
Program pengabdian kepada masyarakat ini adalah kegiatan pendampingan partisipatif yang bertujuan untuk meningkatkan kemampuan dan keterampilan penyusunan silabus pengajian Jamaah Majelis Taklim At-Taqwa Desa Muara Batun Kecamatan Jejawi Kabupaten Ogan Komering Ilir. Pelaksanaan kegiatan terdiri dari tiga tahap. Pertama, tahap persiapan untuk menggali permasalahan terkait pelaksanaan pengajian majelis taklim di lapangan. Kedua, tahap pelaksanaan melakukan koordinasi dan sosialisasi kepada stakeholders sebelum dilakukan pemdampingan partisipatif kepada jamaah majelis taklim. Ketiga, tahap evaluasi dan pelaporan: menganalisis faktor pendukung dan penghambat pelaksanaan kegiatan untuk selanjutnya dilakukan penyusunan laporan kegiatan. Hasil kegiatan ini berdampak pada peningkatan pemahaman dan keterampilan jamaah majelis taklim terhadap teknis penyusunan silabus pengajian, sehingga dimungkinkan jamaah mampu untuk menyusun silabus pengajian majelis taklim secara mandiri.
\end{abstract}

Kata Kunci: Majelis Taklim, Pengajian, Kurikulum, Silabus

\section{A. Pendahuluan}

Makna majelis taklim dapat di lihat dalam Peraturan Menteri Agama Republik Indonesia Nomor 13 tahun 2014 tentang Pendidikan Keagamaan Islam dan Peraturan Menteri Agama Republik Indonesia Nomor 29 tahun 2019 tentang Majelis Taklim, Kementerian Agama Republik Indonesia merumuskan makna majelis taklim sebagai lembaga atau kelompok masyarakat yang menyelenggarakan pendidikan keagamaan Islam nonformal sebagai sarana dakwah Islam. Menurut Helmawati (2013), majelis taklim adalah lembaga atau institusi yang menyelenggarakan pengajaran Agama Islam yang dikelola oleh individu, kelompok, maupun lembaga (organisasi) yang bersifat terbuka terhadap segala usia, lapisan, strata sosial, dan jenis kelamin, serta dilaksanakan di tempat dan waktu yang bersifat fleksibel. 
Keberadaan majelis taklim di tengah-tengah kehidupan masyarakat muslim semakin dirasakan penting. Kegiatan majelis taklim dapat menjadi sarana dan wadah yang efektif, khususnya pembelajaran keagamaan bagi masyarakat, tak hanya kaum tua, juga kaum muda bahkan anak-anak. Majelis taklim menjadi lembaga pendidikan keagamaan alternatif bagi mereka yang tidak memiliki cukup tenaga, waktu, dan kesempatan menimba ilmu agama melalui jalur pendidikan formal. Hal inilah, menurut Hanny Fitriyah, dkk (2012), yang menjadi kekuatan majelis taklim sehingga mampu bertahan, bahkan terus berkembang, dan merupakan lembaga pendidikan Islam yang paling dekat dengan umat (masyarakat).

Kiprah dan peranan penting dari majelis taklim tersebut telah mendapat pengakuan dari pemerintah yang menjadikan majelis taklim sebagai bagian sub sistem pendidikan nasional, sebagaimana tertuang dalam pasal 26 ayat 4 Undang-undang Republik Indonesia Nomor 20 tahun 2003 tentang Sistem Pendidikan Nasional (Sisdiknas), bahwa satuan pendidikan non formal terdiri atas lembaga kursus, lembaga pelatihan, lembaga belajar, dan majelis taklim, serta satuan pendidikan yang sejenis.

Perkembangannya dewasa ini, secara kualitatif, pertumbuhan majelis taklim semakin hari semakin pesat. Berdasarkan database Emis tahun 2012, seperti dikemukakan Direktorat Jenderal Bimbingan Masyarakat Islam Kementerian Agama Republik Indonesia, terdapat lebih dari 165.000 majelis taklim yang ada dan tersebar di seluruh Indonesia (Direktorat Jenderal Bimas Islam dan Direktorat Jenderal Penerangan Agama Islam, 2012). Jumlah tersebut belumlah dapat menggambarkan secara pasti jumlah keseluruhan majelis taklim yang ada di Indonesia dikarenakan terdapat perbedaan pelaporan dari Ormas yang mendata jumlah majelis taklim di Indonesia.

Pertumbuhan yang pesat dalam kuantitas majelis taklim tersebut ternyata tidak sejalan dengan kualitas tata kelola kegiatan majelis taklim. Hal tersebut paling tidak terlihat dalam tata laksana kegiatan pengajian majelis taklim yang dalam pelaksanaannya tidak menggunakan kurikulum yang terpola. Termasuk pengajian Majelis Taklim At-Taqwa Desa Muara Batun Kecamatan Jejawi Kabupaten Ogan Komering Ilir, berdasarkan hasil observasi lapangan diketahui bahwa kegiatan pengajian telah berjalan cukup lama dan dilaksanakan satu minggu sekali dengan materi pengajian diserahkan sepenuhnya kepada nara sumber/pemateri pengajian. Hal inilah yang menarik minat pelaksana untuk melakukan pendampingan penyusunan silabus pengajian majelis taklim sehingga kegiatan pengajian dilaksanakan dengan kurikulum yang terarah dan terukur. 


\section{B. Masalah}

Rumusan masalah dalam pengabdian ini adalah upaya meningkatkan kemampuan dan keterampilan penyusunan silabus pengajian Majelis Taklim At-Taqwa Desa Muara Batun Kecamatan Jejawi Kabupaten Ogan Komering Ilir melalui pendampingan partisipatif.

\section{Metode Pelaksanaan}

Metode pelaksanaan kegiatan pengabdian dilakukan melalui mekanisme yang terstruktur. Pertama-tama, pelaksana akan melakukan observasi lapangan untuk mengetahui kondisi dan permasalahan yang dihadapi oleh jamaah Majelis Taklim At-Taqwa Desa Muara Batun. Setelah mendapatkan gambaran yang jelas terkait permasalahan yang dihadapi, pelaksana melakukan penyusunan rencana kerja untuk selanjutnya didiskusikan bersama dengan pengelola majelis taklim dan stakeholders terkait (tokoh agama dan pemerintahan desa setempat). Tahapan selanjutnya yaitu melakukan penyusunan materi pendampingan untuk disampaikan kepada jamaah pengajian majelis taklim. Pola pendampingan dilaksanakan secara partisipatif, dengan cara penyampaian materi melalui metode ceramah terkait pengelolaan majelis taklim dan silabus pengajian majelis taklim, serta pelibatan peserta dalam penyusunan silabus pengajian majelis taklim.

Struktur Metode pelaksanaan kegiatan seperti tergambar dalam tabel di bawah ini:

Tabel 1. Tahapan Kegiatan dan Rencana Kerja

\begin{tabular}{|c|c|c|c|}
\hline No. & Tahapan Kegiatan & Rencana Kerja & Waktu Pelaksanaan \\
\hline \multirow{3}{*}{1} & \multirow{3}{*}{ Tahap persiapan } & $\begin{array}{l}\text { Observasi lapangan, koordinasi dan } \\
\text { sosialisasi kepada stakeholders }\end{array}$ & 13-15 Januari 2020 \\
\hline & & $\begin{array}{l}\text { Perumusan masalah dan penyusunan } \\
\text { rencana kerja lapangan }\end{array}$ & 20-22 Januari 2020 \\
\hline & & Penyusunan materi pendampingan & $\begin{array}{l}23 \text { Januari- } \\
6 \text { Februari } 2020\end{array}$ \\
\hline 2 & Tahap pelaksanaan & $\begin{array}{l}\text { Pelaksanaan kegiatan pendamping-an } \\
\text { kelompok majelis taklim }\end{array}$ & 8 Februari 2020 \\
\hline \multirow{2}{*}{3} & \multirow{2}{*}{$\begin{array}{l}\text { Tahap evaluasi dan } \\
\text { pelaporan }\end{array}$} & Evaluasi pelaksanaan kegiatan & 10-13 Februari 2020 \\
\hline & & penyusunan laporan kegiatan & 16-22 Februari 2020 \\
\hline
\end{tabular}




\section{Pembahasan}

\section{Tahapan Pelaksanaan Pengabdian Kepada Masyarakat}

a. Tahap persiapan

Pada tahap persiapan ini kegiatan yang dilakukan meliputi 3 (tiga) tahap, yaitu: pertama, observasi lapangan (koordinasi dan sosialisasi kepada stakeholders) Observasi lapangan ini sebagai survey pelaksana, yang bertujuan untuk mengumpulkan data awal permasalahan yang relevan dengan konteks pengabdian, keadaan penduduk, serta data pendukung lainnya yang dinilai penting. Kegiatan ini dilaksanakan selama 3 (tiga) hari dengan kunjungan lapangan ke Desa Muara Batun untuk berkonsultasi dan berkoordinasi dengan Kepala Desa dan perangkat pemerintahan Desa Muara Batun, tokoh agama, tokoh masyarakat, dan pengelola majelis taklim.

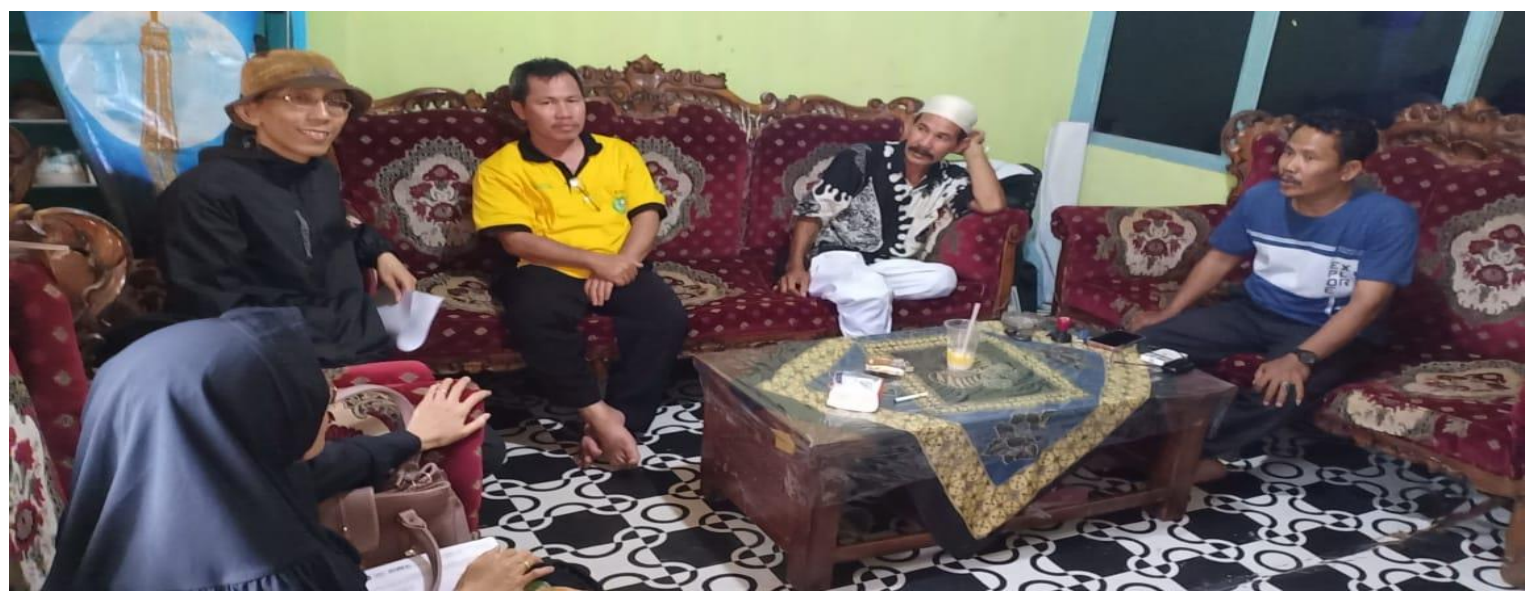

Gambar 1. Koodinasi Bersama Kepala Desa, Tokoh Agama, dan Pengelola Majelis Taklim At-Taqwa Desa Muara Batun

Kedua, perumusan masalah dan penyusunan rencana kerja lapangan. Dalam observasi lapangan yang telah dilakukan diperoleh informasi bahwa kegiatan pengajian yang dilaksanakan oleh majelis taklim di Masjid Istiqomah Desa Muara Batun telah berjalan cukup lama dan dilaksanakan setiap satu minggu sekali, yaitu pada Hari Kamis setelah shalat dzuhur. Melalui wawancara dan pengamatan lapangan diketahui bahwa kegiatan pengajian berada di bawah asuhan salah satu tokoh agama Desa Muara Batun, H. Bachrodi. Materi pengajian yang disampaikan dalam setiap kegiatan pengajian sepenuhnya diserahkan kepada pengasuh. Hal inilah yang menarik pelaksana pengabdian untuk dijadikan sebagai latar belakang permasalahan dalam pengabdian ini. 


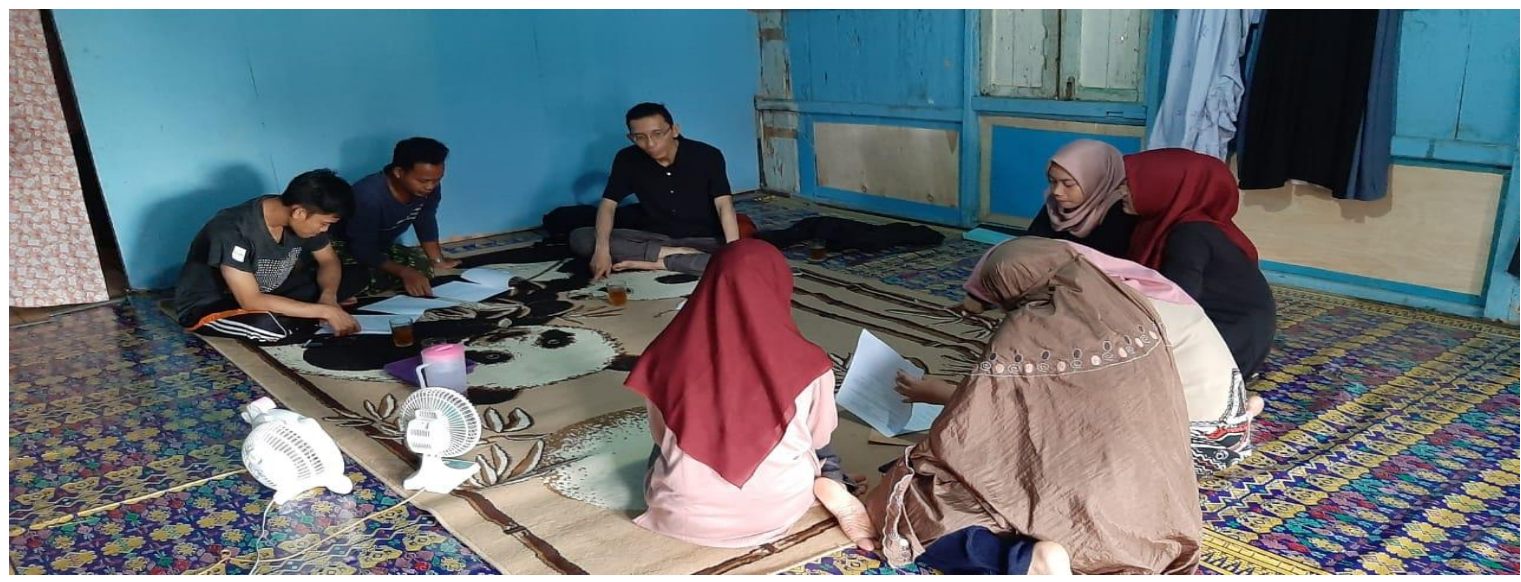

Gambar 2. Penyusunan dan Sosialisasi Rencana Kerja Lapangan

Ketiga, penyusunan materi pendampingan. Materi pendampingan yang akan disusun merujuk kepada data observasi lapangan yang menjadi rumusan masalah untuk dicarikan solusinya. Materi pendampingan yang akan diberikan berkaitan dengan pengelolaan majelis taklim dan teknis penyusunan silabus pengajian majelis taklim.

b. Tahap pelaksanaan

Tahap ini adalah tahapan inti kegiatan. Pelaksanaan kegiatan pembinaan jamaah majelis taklim dilakukan melalui pola pendampingan partisipatif. Pada tahap pertama pelaksanaan kegiatan, pelaksana melakukan penyusunan rencana kerja sesuai dengan jadwal kegiatan yang telah direncanakan, untuk selanjutnya didiskusikan bersama pengelola majelis taklim dan dikoordinasikan kepada stakeholders terkait (tokoh agama dan pemerintahan Desa Muara Batun).

Tahapan selanjutnya yaitu melakukan penyusunan silabus pengajian majelis taklim bersama dengan jamaah Majelis Taklim At-Taqwa Desa Muara Batun melalui pendampingan partisipatif, dengan cara penyampaian materi melalui metode ceramah terkait pengelolaan dan silabus pengajian majelis taklim dan pelibatan peserta dalam penyusunan kurikulum majelis taklim. Penyampaian materi, seperti dijadwalkan bersama pengurus majelis taklim, yaitu pada Hari Sabtu, 8 Februari 2020 pukul 13.30 WIB (setelah shalat dzuhur) sampai dengan pukul 15.30 WIB (sebelum shalat ashar), bertempat di Masjid Istiqomah Desa Muara Batun. Namun, karena kondisi sedang hujan banyak peserta yang tidak dapat datang sesuai jadwal sehingga kegiatan baru dimulai pada 14.00 WIB dan diakhiri pada 16.30 WIB, setelah shalat ashar berjamaah. Dalam hubungan itu, peserta 
yang diharapkan dapat hadir dalam kegiatan ini adalah seluruh anggota Majelis Taklim At-Taqwa Desa Muara Batun yang berjumlah sekitar 70 orang. Adapun peserta yang hadir sampai dengan kegiatan dimulai pada pukul 14.00 WIB berjumlah 51 orang.

Selanjutnya, materi yang disampaikan kepada peserta kegiatan berupa materi terkait pengelolaan kegiatan majelis taklim dan materi silabus pengajian majelis taklim yang digali melalui kajian teoritis dalam buku rujukan yang pelaksana gunakan, seperti "Pedoman Majelis Ta'lim" yang diterbitkan oleh Kementerian Agama Republik Indonesia dan "Manajemen dan Silabus Majelis Taklim" yang diterbitkan oleh Pusat Pengkajian dan Pengembangan Islam Jakarta. Materi yang telah disusun tersebut selanjutnya disampaikan kepada pengelola majelis taklim untuk disebarluaskan kepada jamaah majelis taklim dan dibahas dalam penyampaian materi pada tanggal 8 Februari 2020.

Setelah penyampaian materi, diberikan ruang untuk tanya jawab dan berdiskusi terkait rencana silabus yang akan diterapkan dalam kegiatan pengajian di Majelis Taklim At-Taqwa Desa Muara Batun untuk dijadikan pedoman pelaksanaan kegiatan pengajian Majelis Taklim At-Taqwa Desa Muara Batun. Dalam sesi tanya jawab tersebut, terlihat sekali antusiasme peserta untuk bertanya dan berdiskusi menentukan kurikulum yang paling sesuai dengan kebutuhan jamaah Majelis Taklim At-Taqwa Desa Muara Batun.

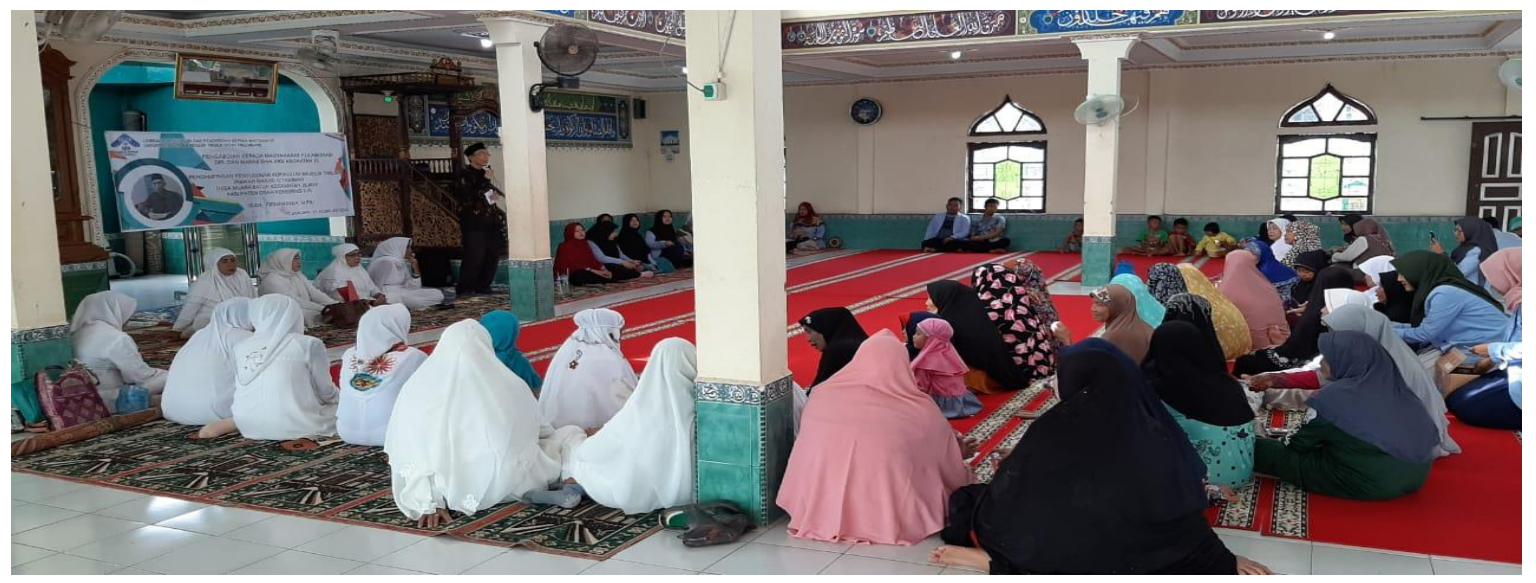

Gambar 3. Penyampaian Materi Pendampingan Kepada Jamaah Majelis Taklim AtTaqwa di Masjid Istiqomah Desa Muara Batun

c. Tahap evaluasi dan pelaporan

Tahap ini adalah tahapan akhir dari kegiatan, yaitu evaluasi pelaksanaan kegiatan dan penyusunan laporan kegiatan yang telah dilaksanakan. Tahapan ini dilaksanakan pada 
minggu ketujuh dalam rangkaian rencana kerja, yaitu pada tanggal 10-13 Februari 2020. Berdasarkan hasil evaluasi kegiatan, diketahui bahwa faktor-faktor yang mendukung lancarnya pelaksanaan kegiatan, yaitu: a). antusiasme jamaah majelis taklim untuk memahami materi kegiatan; dan b). Adanya dukungan dan bantuan dari pemerintahan Desa Muara Batun, tokoh agama, tokoh masyarakat, masyarakat Desa Muara Batun, khususnya pengelolaa dan jamaah Majelis Taklim At-Taqwa Desa Muara Batun, serta mahasiswa peserta KKN Reguler ke-72 UIN Raden Fatah Palembang Tahun 2020. Di samping faktor pendukung tersebut, beberapa hal yang teridentifikasi menjadi faktor penghambat kegiatan, yaitu: a). kondisi cuaca yang sedang berada di musim penghujan yang menyebabkan terhambatnya mobilitas pelaksanaan kegiatan; dan b). keterbatasan waktu penyampaian materi kepada jamaah Majelis Taklim At-Taqwa Desa Muara Batun.

Selanjutnya, setelah semua tahapan kegiatan dilaksankaan, dilakukan penyusunan laporan pelaksanaan kegiatan pengabdian. Penyusunan laporan kegiatan dilaksanakan selama 7 hari, yaitu pada tanggal 16-22 Februari 2020.

\section{Hasil Kegiatan Pengabdian Kepada Masyarakat}

Kegiatan pengabdian ini berjalan dengan lancar dan dinilai cukup berhasil, serta mendapatkan respon yang baik dari perangkat Desa Muara Batun, tokoh agama, tokoh masyarakat, dan masyarakat Desa Muara Batun. Keberhasilan pelaksanaan kegiatan ini mencakup beberapa komponen di bawah ini:

1. Ketercapaian target jumlah peserta yang mengikuti kegiatan. Anggota jamaah Majelis Taklim At-Taqwa Desa Muara Batun berjumlah sekitar 70 orang. Dari jumlah tersebut, pelaksana menargetkan kehadiran peserta sebanyak minimal 50\% atau 35 orang. Berdasarkan data daftar hadir peserta, jumah peserta yang mengikuti kegiatan sebanyak 51 orang atau $73 \%$ dari total jumlah anggota majelis taklim.

2. Ketercapaian penyampaian materi yang telah direncanakan. Penyampaian materi kegiatan oleh pelaksana kepada jamaah majelis taklim, peserta kegiatan, sebanyak 2 (dua) materi pokok bahasan, yaitu: pengelolaan majelis taklim dan silabus pengajian majelis taklim. Materi tersebut telah disusun sedemikian rupa untuk disampaikan dengan durasi maksimal 90 menit. Walaupun sempat terkendala kondisi cuaca yang hujan, sehingga pelaksanaan yang dijadwalkan dimulai pukul 13.00-15.30 WIB baru dapat dilaksanakan pada pukul 14.00-16.30 WIB. Pelaksana dapat memaksimalkan waktu dengan efektif dan efisien, 
sehingga materi yang telah direncanaka dapat disampaikan dengan baik kepada peserta kegiatan.

3. Ketercapaian tujuan kegiatan. Tujuan pelaksanaan kegiatan ini adalah tersusunnya silabus pengajian majelis taklim sesuai dengan kebutuhan mitra. Setelah mengikuti rangkaian kegiatan pengabdian, pemahaman jamaah majelis taklim terhadap pengetahuan pengelolaan majelis taklim dan penyusunan silabus pengajian majelis taklim dinilai semakin meningkat. Peningkatan pemahaman tersebut berindikasi pada peningkatan keterampilan jamaah majelis taklim terhadap teknis penyusunan silabus pengajian, sehingga dimungkinkan jamaah mampu untuk menyusun silabus pengajian majelis taklim secara mandiri.

\section{E. Kesimpulan}

Kegiatan pendampingan Penyusunan Silabus Pengajian Majelis Taklim At-Taqwa Desa Muara Batun Kecamatan Jejawi Kabupaten Ogan Komering Ilir telah dilaksanakan dengan baik dan lancar sesuai dengan rencana kerja yang telah disusun. Hasil kegiatan pengabdian ini dirasakan sangat bermanfaat bagi masyarakat, khususnya oleh jamaah Majelis Taklim At-Taqwa Desa Muara Batun. Dalam pelaksanaannya, kegiatan ini dinilai cukup berhasil dan mendapatkan respon dan dukungan yang baik dari tokoh agama, tokoh masyarakat, dan perangkat Desa Muara Batun, serta diikuti secara antusias oleh jamaah Majelis Taklim At-Taqwa Desa Muara Batun. Keberhasilan pelaksanaan kegiatan ini mencakup beberapa komponen yaitu: (1) Ketercapaian target jumlah peserta yang mengikuti kegiatan, yaitu mencapai $73 \%$ dari target peserta sebanyak 50\%; (2) Ketercapaian penyampaian materi yang telah direncanakan; (3) Ketercapaian tujuan kegiatan, yaitu adanya peningkatan pemahaman dan keterampilan jamaah majelis taklim terhadap teknis penyusunan silabus pengajian, sehingga dimungkinkan jamaah mampu untuk menyusun silabus pengajian majelis taklim secara mandiri.

\section{DAFTAR PUSTAKA}

Hanny Fitriyah, dkk (2012). Manajemen dan Silabus Majelis Taklim. Jakarta: Pusat Pengkajian dan Pengembangan Islam Jakarta (Jakarta Islamic Centre).

Helmawati, (2013). Pendidikan Nasional dan Optimalisasi Majelis Ta'lim: Peran Aktif Majelis Ta'lim Meningkatkan Mutu Pendidikan. Jakarta: Rineka Cipta. 
Peraturan Menteri Agama Republik Indonesia Nomor 13 Tahun 2014 tentang Pendidikan Keagamaan Islam dan Peraturan Menteri Agama Republik Indonesia Nomor 29 tahun 2019 tentang Majelis Taklim.

Tim Penyusun Materi Pedoman Majelis Ta'lim (2012). Pedoman Majelis Ta'lim. Jakarta: Direktorat Jenderal Bimas Islam dan Direktorat Jenderal Penerangan Agama Islam Kementerian Agama Republik Indonesia.

Undang-undang Republik Indonesia Nomor 20 Tahun 2003 tentang Sistem Pendidikan Nasional. 